\title{
APPLICATION OF THE "UNSEAWORTHINESS" DOCTRINE TO LONGSHOREMEN
}

\section{Leighton Shumids, Jr. $\dagger$ and Thomas E. Byrne, JR. $\ddagger$}

Clarity of thought is not promoted when, by an accident of linguistic history, two unlike things are called by the same name. Growth by analogy has been one of the law's great strengths but when the analogy hit upon is false the result is confusion and stalemate. ${ }^{1}$

In the more than sixteen years which have passed since the Supreme Court's decision in Seas Shipping Co. v. Sieracki, ${ }^{2}$ there have been sweeping changes in the maritime law and the maritime industry. The Sieracki decision plowed new ground by extending the "warranty of seaworthiness" to longshoremen. The object of this Article will be to examine the extent to which this doctrine has developed, the legitimacy of the reasons set forth in support of the doctrine, the effect which it has had upon the maritime industry, and the policy questions which can now be viewed in perspective.

\section{The Present Status of the Shipowner's Liability to SHORESIDE WORKERS FOR "UNSEAWORTHINESS"}

To practitioners of maritime law, no review of the Sieracki case is necessary. Stated briefly, a shipowner had entered into a contract with Sieracki's employer, an independent contracting stevedore. ${ }^{3}$ Sieracki was engaged in the loading of a piece of large equipment into the ship's hold. He was injured when, due to a flaw in its manufacture, a shackle supporting part of the ship's loading gear broke. The shipowner and the shipbuilder were codefendants in the original litigation. ${ }^{4}$ The trial court held the shipbuilder liable for negligence in installing the defective shackle, but the shipowner was held not liable

$\dagger$ B.A. 1948, Bates College; M.A. 1950, Harvard University.

$\ddagger$ B.S. 1934, University of Notre Dame; LL.B. 1938, Temple University. Member, Pennsylvania Bar. Mr. Byrne was counsel for petitioner in Seas Shipping Co. v. Sieracki, 328 U.S. 85 (1946).

1 GIIMORE \& BLACK, ADMIRALTY 483 (1957).

2328 U.S. 85 (1946).

3 Longshoremen "refers to the laborers who do the actual physical work, whereas the stevedore is the contractor or boss who employs longshoremen." DE Kerceove, InTERaAtional Maritinte DictionaRy 432 (1948).

4 Sieracki v. Seas Shipping Co., 57 F. Supp. 724 (E.D. Pa. 1944). 
since a reasonable examination would not have disclosed the defect. On appeal, ${ }^{5}$ the Court of Appeals for the Third Circuit held that the shipowner was liable even though he had not been negligent. The Supreme Court, over vigorous dissent, affirmed, stating that "historically the work of loading and unloading . . . [was] performed until recent times by members of the crew" "and that the longshoreman "is, in short, a seaman because he is doing a seaman's work . . . ." T

From the longshoreman working on board ship, the application of the "warranty of seaworthiness" has been extended to a shore-based carpenter on board to fit out the ship for its voyage, ${ }^{8}$ and to the employee of a ship repair company brought aboard to make repairs. ${ }^{\ominus}$ The warranty covers the employee injured by equipment which the stevedoring contractor brings aboard, ${ }^{10}$ and applies even if the employee, acting against orders, has created the dangerous condition which produced his injury. ${ }^{11}$ In fact, almost any employee of a contractor, ${ }^{12}$ working aboard ship, who asserts that his work was historically and traditionally performed by seamen-sailors aboard a ship in the course of their employment-seems to be covered by the warranty.

Unseaworthiness has even come ashore. The first such case was Strika $v$. Netherlands Ministry of Traffic, ${ }^{13}$ in which a longshoreman working on a pier was injured by a piece of ship's equipment. The doctrine has now been extended to cover a man injured while working on the dock a hundred feet from the ship. ${ }^{14}$ A sandlike substance packaged in bags had been transported by ship. Some of the bags were torn and one of the workmen was injured when he slipped in a pile of the sand which had accumulated about a hundred feet inside the pier. In another instance, the doctrine was extended to a longshoreman working on a pier who was run over by a railroad car. ${ }^{15}$

5149 F.2d 98 (3d Cir. 1945).

6328 U.S. 85, 96 (1946).

7 Id. at 99 .

8 Pope \& Talbot, Inc. v. Hawn, 346 U.S. 406 (1953) ; Mesle v. Kea S.S. Corp., 260 F.2d 747 (3d Cir. 1958), cert. denied, 359 U.S. 966 (1959).

9 Lawlor v. Socony-Vacuum Oil Co., 275 F.2d 599 (2d Cir. 1960).

10 Petterson v. Alaska S.S. Co., 205 F.2d 478 (9th Cir. 1953), aff'd per curiam, 347 U.S. 396 (1954).

11 Holley v. The Manfred Stansfield, 186 F. Supp. 212 (E.D. Va. 1960).

12 If the employee is working directly for the shipowner, his recovery is limited to compensation under the Longshoremen's and Harbor Workers' Compensation Act, which states that the employer's liability to the employee under the act shall be "exclusive and in place of all other liability . . ." 44 Stat. 1426 (1927), 33 U.S.C. $\S 905$ (1958).

13185 F.2d 555 (2d Cir. 1950), cert. denied, 341 U.S. 904 (1951).

14 Hagans v. Ellerman \& Bucknall S.S Co., 196 F. Supp. 593 (E.D. Pa. 1961). 15 Thompson v. Calmar S.S. Corp., Civil No. 26450, E.D. Pa., Oct. 25, 1962. 
II. The Warranty of Seaworthiness to Non-Seamen: AN Historical View

\section{A. The Legal Background}

Courts have imposed and extended liability on the basis of the Supreme Court's conception that longshoremen do work formerly done by seamen. Research of ancient and recent decisions, however, unearthed but a single case in which a crew member was injured while handling cargo, ${ }^{16}$ and the facts of that case-a lumber company ship transporting its own cargo on a short voyage-distinguish it from the usual situation.

In Sieracki, the Court cited Atlantic Transp. Co. v. Imbrovek ${ }^{17}$ for the proposition that an injury to a stevedore is a maritime tort. ${ }^{18}$ The Court cited Florez v. The Scotia, ${ }^{10}$ The Gilbert Knapp, ${ }^{20}$ The Seguranca, ${ }^{21}$ and its own prior holding in International Stevedoring Co. $v$. Haverty $^{22}$ as support for its statement that the work of loading and unloading was historically and traditionally work performed by sailors. $^{23}$ These three cases and all of the cases cited by Mr. Justice Hughes in Imbrovek ${ }^{24}$ deal only with the question of whether a stevedore is entitled to a maritime lien. It had previously been held that the work of loading and unloading cargo was not a maritime service and that therefore stevedores were not entitled to maritime liens for their services. To grant such a lien, a court need only have found that the stevedore's services were maritime in nature. This conclusion can be reached without holding that cargo handling operations were formerly conducted by the crew. Therefore, statements to that effect are only dicta. History shows these statements to be inaccurate.

In 1799 the court in Swift $v$. The Happy Return, stated:

In this port [Philadelphia], it is the general custom to hire others than the mariners to lade and unlade vessels. The

16 Coos Bay Lumber Co. v. Pillsbury, 37 F. Supp. 914 (N.D. Cal. 1941) (seaman killed while operating a winch during unloading of ship).

17234 U.S. 52 (1914).

18328 U.S. at 91.

1935 Fed. 916 (S.D.N.Y. 1888).

2037 Fed. 209 (E.D. Wis. 1889).

2158 Fed. 908 (S.D.N.Y. 1893).

22272 U.S. 50 (1926).

23328 U.S. at 90.

24234 U.S. 52, 62 (1914), citing: Norwegian S.S. Co. v. Washington, 57 Fed. 224 (5th Cir. 1893); The Main, 51 Fed. 954 (5th Cir. 1892); The Allerton, 93 Fed. 219 (D. Ore. 1899); The Seguranca, 58 Fed. 908 (S.D.N.Y. 1893) ; The Gilbert Knapp, 37 Fed. 209 (E.D. Wis. 1889); The Hattie M. Bain, 20 Fed. 389 (S.D.N.Y. 1884); The Canada, 7 Fed. 119 (D. Ore. 1881); Roberts v. The Bark Windermere, 2 Fed. 722 (S.D.N.Y. 1880); The George T. Kemp, 10 Fed. Cas. 227 (No. 5341) (D. Mass. 1876); The Circassian, 5 Fed. Cas. 702 (No. 2722) (E.D.N.Y. 1867). 
merchants find it more for their interests so to do, than to depend on the mariners, who are particularly ungovernable after a voyage is ended; and are, when arrived at home, impatient under confinement to the drudgery of unlading the cargo. ${ }^{25}$

Peters' Admiralty Decisions is probably the earliest collection of American decisions in maritime cases. ${ }^{26}$ Peters' comments clearly indicate that under ancient maritime codes the sailors did not load or unload cargo, ${ }^{27}$ but that it was done by employees of the merchant who owned the cargo. ${ }^{28}$ The ancient maritime codes show that, at most, the sailor's agreement with the ship's master gave the latter the right to keep enough of the crew on board while in port to tend to the ship's safety. ${ }^{29}$

\section{B. A Survey of History}

\section{The United States}

One writer said that, in making its statement in Imbrovek, "the Court remembered that this kind of work, as Dana vividly revealed to us in his classic, used to be done by the seamen, the crew of the ship . . . ."30 At one point Dana describes the crew carrying hides from carts and throwing them off a cliff to the beach below and then hauling them to the ship anchored offshore. ${ }^{31}$ But this was not a normal harbor; a nearby mission or ranch was the source of cargo. Dana made uncomplimentary references to the industry of the inhabitants of Spanish California and pointed out that they "have no boats of their own" with which to do the work. ${ }^{32}$ Thus the crew handled

25 Swift v. The Happy Return, 23 Fed. Cas. 560, 561 (No. 13697) (D. Pa. 1799). 26 Peters' collects maritime cases in Philadelphia between 1780 and 1806. Portions of its appendices are printed in 30 Fed. Cas. 1171 (1897).

27 "In France the owners of ships receiving freight, are not obliged to pay the expenses of loading or unloading, but they form a separate charge against the owners of the cargo." Laws of Oleron, 30 Fed. Cas. 1171, 1176 n.10 (1897).

28 Peters' notes that the merchant loaded the ship, and that in the ports of Guyenne there were

certain officers called "arrameurs" or stowers, who were master-carpenters by profession, and were paid by the merchants, who loaded the ship. Their business was to dispose right, and stow closely all goods in casks. . . . There were also sacquiers, who were very ancient officers, as may be seen in the 14th book of the Theodosian Code, Unica de Saccariis Portus Romae, lib. 14. Their business was to load and unload vessels laden with salt, corn or fish....

30 Fed. Cas. at 1177.

29 Article V, Laws of Oleron, provided that so long as there remained "a sufficient number of men aboard to keep the decks and lading," the rest of the crew might go ashore even without the master's consent if they returned "in good time." 30 Fed. Cas. at 1173.

30 McFee, The Law of the Sea 175 (1950).

31 Dana, Two Years Before the Mast 209-10 (Modern Library ed. 1936).

32 Id. at 78. 
cargo when there was a complete lack of facilities and no local harbor. When Dana left Boston in 1834 on the brig Pilgrim he did not load cargo, since he arrived on board only a few hours before sailing. ${ }^{33}$ When he returned to Boston two years later on board the brig Alert, the crew had nothing to do with cargo. The crew members manned the capstan, hauled the vessel to the wharf, and "the last turn was made fast and the crew dismissed; and in five minutes more not a soul was left on board the good ship Alert but the old ship-keeper, who had come down from the counting-house to take charge of her." 34

The Supreme Court's concept of the ancient mariner loading and unloading his ship as well as sailing her may sound plausible and be romantically appealing, but it is inaccurate. It does not portray recorded history except in unusual circumstances such as Dana's experience on the California coast.

Herman Melville was one of the more lucid chroniclers of American maritime history. Of a voyage he made to Liverpool in 1837, he wrote: "As we had nothing to do with the cargo, of course, our duties were light enough; and the chief mate was often put to it to devise some employment for us." ${ }^{35}$ Melville again points out that while the crew was busy getting things ready for sea "the cargo had been already stowed in the hold by the stevedores and lumpers from shore." ${ }^{36}$

Some packet lines maintained their own stevedores and crews of longshoremen for the loading and unloading of the ships. ${ }^{37}$ Usually however, stevedores have been independent of the shipping lines. It must be remembered that the handling of the cargo was not an unplanned, unskilled operation-but required the combination of trained supervisors and hard muscle. ${ }^{38}$

An instance in which a crew did unload its own vessel in the United States was that of the Canton Packet in 1821, but this was a favor on the part of the captain since "he allowed the crew to discharge the ship, receiving stevedores' wages and to strip the vessel for laying up, receiving riggers' wages." 39 This further illustrates that the handling of the cargo was not the normal function of the crew, but was performed for extra pay and under unusual circumstances. In the port of Canton itself, cargo handling was an organized trade. The only way to do business with the Chinese Empire was through a monopolistic

33 Id. at 3.

$34 I d$. at 386.

35 Melville, RedbuRN 174 (Standard ed. 1922).

$36 \mathrm{Id}$. at 309 . Lumpers are laborers who do the work of loading and unloading. KIRKAIDY, BRITISH SHIPPING 478 (1914).

37 Aldion, Rise of New York Port 223 (1939).

38 Id. at 223.

381 Porter, The Jacksons aNd the Lees 11 (1937). 
organization known as the Co-Hong which "took all the necessary steps and paid all the necessary sums to have the cargo discharged into privileged 'monopoly' lighters and brought to the factory." 40

There are a number of classic accounts of the seaman's life aboard ship written by men who spent a great portion of their lives at sea, as opposed to men like Dana and Melville whose time at sea was comparatively short. The account left by Samuel Kelly ${ }^{41}$ deals mainly with the 1780's. He does not mention crew members handling cargo. All references indicate that longshoremen of various kinds performed this work. While at Jamaica in 1781, Kelly described a "gang" bringing chests of Castile soap from the ship to shore. ${ }^{42}$ Also, in 1782, he talks of "the lumpers" at Deptford who had been employed on board the ship in connection with loading operations prior to the shipping of the crew. ${ }^{43}$ In 1788, when his ship was anchored in the Thames, Kelly apparently was a watchman over the "many watermen on board," for he describes catching one of them stealing sugar. ${ }^{44}$

The writings of Captain Samuel Samuels ${ }^{45}$ cover many years at sea. The only case in which Samuels speaks of the crew having participated in cargo loading operations was when his ship called at Odessa during the plague. Lighters were set adrift near the vessel, caught, loaded by the crew, and again set adrift to be picked up by the Russians. ${ }^{46}$ Conversely, Samuels speaks of having paid his crew off and then remaining in Hamburg because "the discharging of our cargo occupied three weeks." 47

In addition to the works already mentioned, there exist records in diaries, books of account, and business biographies, which demonstrate that the work of loading and unloading was not performed by the trained seamen, who were anxious to get ashore on completion of the voyage and similarly anxious to stay there until the last moment before sailing.

In 1790 Salem's Union Wharf had a prescribed set of charges which was accepted by other pier and wharf owners. ${ }^{48}$ Unloading of barrels was one cent each; ballast and brick were unloaded at eight cents per ton; the charge for bales or boxes was five cents each.

40 Morse, The Trade and Administration of China 286 (rev. ed. 1913).

41 Samuei Keily: An Eighteenth Century Seaman (Garstin ed. 1925),

$42 \mathrm{Id}$. at 35 .

$43 \mathrm{Id}$. at 73 .

44 Id. at 160.

45 Samueis, From the Forecastle to the Cabin (1887).

46 Id. at 193.

47 Id. at 240. The length of time may be attributed to the fact that the cargo was sold on a piecemeal basis to obtain greater profit.

481 Bentley, Diary 143 (1905). 
Some of the founding fathers would have been surprised at the concept of sailors loading and unloading, for the books of John Hancock's firm reveal the payments of "charges for cleaning out ballast 29.17.3." 48 The entry in question was dated 1754. There were complaints of other merchants about unloading charges at Lisbon and in Ireland in $1774 .^{50}$ Correspondence between owners and captains makes it clear that the cost of handling cargo was distinct from the cost of vessel operation, which included crew's wages.

Thomas Bailey Aldrich described Portsmouth in the middle 18th century when it had become a "ghost town."

There are no ships lying at the pier-heads; there are no gangs of stevedores staggering under heavy cases of merchandise . . . [A]t the windows of these musty counting-rooms . . . used to stand portly merchants .. . waiting for their ships to come up the Narrows; the cries of stevedores and the chants of sailors at the windlass . . . . ${ }^{51}$

\section{Great Britain}

The substantial difference between water level at high and low tides had a significant effect upon the English handling of cargo, particularly at London. These tides prevented all but the smallest flatbottom vessels from mooring to a wharf. Most vessels entering English ports, particularly London, moored in mid-river at such well-known anchorages as Deptford, Blackwall, and North Fleet. Much of the cargo was in barrels which were rolled from the ship onto lighters tied alongside. $^{52}$ This method could only be effectively employed through the overall direction of experienced stevedores using their own men. The City Corporation of London "claimed immemorially the right" of regulating everything connected with the "unloading and delivery of merchandise imported into the port." 53 The "porters" who handled the cargoes were tightly organized into brotherhoods, with each handling goods based upon type, point of origin, or destination. The "ticket porters handled and shipped off goods imported from or exported to all parts of America." 54 This guild or union became so strong that by the middle of the eighteenth century "no labour in the port could be performed by any other person whilst there was a sufficient number of these men offering themselves." 55

49 BAXter, The House of Hancock 126 (1945).

501 Massachusetts Historical Society, Commerce of Rhode Island 17261800 , at 478 (1914).

51 AlDRice, AN Old Town by the SEa 9-11 (3d ed. 1894).

52 Broodbank, History of tHe Port OF LONDON 372, 409 (1921).

$53 \mathrm{Id}$. at 409 .

54 Id. at $427-28$.

65 Id. at 430 . 
Commencing in 1802, huge wetdocks were opened. These were surrounded by high stone walls, contained extensive storage warehouse space, and were equipped with locks to keep the water at a constant level. Once inside the dock with the lock closed, a ship could tie to the wharf unaffected by the tides. After a vessel had entered such a wetdock "all her crew save for one responsible officer, had to leave her. Only men employed by the dock company were allowed to discharge under the direction of one of the company's own foremen." ${ }^{58}$ The porters who had formerly loaded and unloaded ships in the stream were absorbed into the personnel of the dock company. ${ }^{57}$

Each dock had its permanent laborers and its extra men, varying from 200 permanent men for the West India Dock Company to 24 permanent men for the East India Dock Company, which had some hundred other men employed as lumpers or laborers. ${ }^{58}$ Large numbers of casual laborers were needed because of the seasonal nature of the trade and the irregular arrival of vessels. Even during the London dock strike of 1889 , vessels were not unloaded by their crews, but were diverted to Antwerp and Rotterdam for unloading. ${ }^{58}$

There has always been this emphasis upon specialization of labor to perform efficiently the various tasks, whether sailing the vessel or loading and unloading it. The economic needs of the owner dictated that the vessel lie idle in port only a minimum length of time. A member of the crew was normally not expected to participate in the handling of cargo. If it was done by crew members in an emergency the sailor was paid extra for the work. This was practically never done in an organized port, and it was never the case that longshoremen. proceeded to sea with the vessel as crew members. Longshoremen never encountered the real "perils of the sea" as did the sailor. Seamanship in the days of sail was a specialized activity, requiring four or more years of training at sea before a man was rated as an able seaman and paid as such. A sailor signed on a ship for a voyage, appeared immediately before sailing, and left the ship promptly when the voyage was concluded. While to a landsman the work of sailing a ship and the work of loading and unloading it may both seem maritime in nature, to a sailor only running the ship is maritime. ${ }^{60}$

Even in medieval England the differentiation between sailor and longshoreman was maintained. "The task of discharging salt from

56 Grosvenor, The Port of London 64 (1957).

67 Broodbank, op. cit. supra note 52, at 431.

58 Id. at 431,434 .

59 Id. at 443 .

60 See Grosvenor, op. cit. supra note 56, at 64. See also Thornton, British SHIPPING 255-57 (1945); VILliers, The WAY OF A ShIP (1953). 
these ships was generally performed by special porters whose terms of hire were prescribed by the town council of the port where they worked." ${ }^{61}$ This was true of Bristol as well as London. We find that in November 1282 unloading at Vintry Wharf, London, was performed by "four gangs of wyndrawers of twelve men each, for the union rule is that there shall never be less than twelve men to a job of this sort." ${ }^{2}$ A high degree of specialization also existed in the middle ages, with certain wharves handling certain products only. "There were other fees for hoisting the casks, placing them on the wharf, and removing them to warehouses or cellars in the town. This work was usually done by special privileged gangs; at Ipswich the 'beremen', porters, or 'wyndrawers' consisted of a master and twelve men." 63

Significantly, during this entire period, and for centuries before, the guild system was strong in England and elsewhere. One authority on the guild system writes: "The Thames lighterman and the Billingsgate porter are perhaps the most picturesque, as they are certainly the most ancient, types of London industry. Their modes of work have varied very little during the twenty centuries which have elapsed since the Romans brought them-if indeed they did not find them." 64 The porters at Queenhithe and Billingsgate Wharves, working under the supervision of the Corn and Salt Meters, were long-established by the 13th century and retained their jurisdiction to the middle of the 19th century. ${ }^{65}$ Unwin, referring to two groups of street porters and ticket porters, says :

[B] esides these two bodies, there were two others-the predecessors of the modern stevedores-who worked on the wharves and in the vessels lading and unlading; one section being employed by the Tackle House Porters appointed by the twelve great companies to handle the goods of English merchants, and the other section being under the direction of the Packer appointed by the city to superintend lading and unlading of the goods of foreign merchants. ${ }^{66}$

\section{Ancient History}

Since Greek cities depended upon revenue from harbor or customs dues, the harbors were well-organized. ${ }^{67}$ Sailors or mariners are

61 Bridbury, England and the Salt Trade in the Later Mmdre Ages 136-67 (1955).

62 Unwin, Finance and Trade Under Edward III, at 22 (1918).

63 Salzaran, English Trade in the Middle Ages 397 (1931).

64 Unwin, The Guilds and Companies of London 352 (1908).

65 Id. at 359.

66 Id. at 360.

67 See Casson, The Anctent Martners 112 (1959); Michell, The Economics of ANCIENT Greece 257 (2d ed. 1957). 
mentioned as separate categories from the men who loaded or unloaded the vessels. ${ }^{68}$ There were guild organizations of harbor porters, ${ }^{69}$ and the separation of categories of endeavor according to guilds was universal. ${ }^{70}$

Tenney Frank, an authoritative writer on ancient Rome, makes clear the distinction between the men who sailed the ships and those who did the labor on or about them while in port. This was due in part to the separate guilds for shipwrights, stevedores [stuppartores], the dock hands who loaded sand ballast [saburrarii], the unloaders of grain in sacks [saccarii], and the general laboring longshoremen [geruli]. ${ }^{71}$ Perhaps another reason for the distinction was that the mariners who sailed the ships were of the warrior class. One of their main duties was defense of the vessel against pirates. ${ }^{72}$ Lack of navigational instruments forced the ships to sail close to shore, and piracy was common. ${ }^{73}$ Vessels bound for Rome had to be unloaded at Ostia, a port constructed about 44 B.C. at the mouth of the River Tiber. From there the cargoes were taken by tenders and barges up the river to the city. Frank comments upon the difficulty of making calculations as to the cost of shipment of cargoes because the work of transshipment from the ocean going vessels to the barges and lighters was performed by day laborers. ${ }^{74} \mathrm{He}$ attributes the lack of more precise information "to the increasing practice of having work performed by contract and of recording only the sum paid for the entire task without giving enough particulars to make it possible to determine the pay per day for the labor involved." 75 He also states that the unloaders of grain would go out in small craft to meet the ocean going ship, would trans-ship the cargo, and bring it ashore so that the ocean going ships could sail again as quickly as possible. He notes further that "the inscriptions at Ostia indicate the presence of thousands of laborers in the service, working as measurers, stevedores, bargemen, warehouse men and record keepers . . . ." 76

Historical evidence thus clearly indicates that the work of loading and unloading ships was never the traditional work of the mariners who sailed them. That is not to say that crew members never did this

68 Glotz, ANcient Greece at Work 171, 301 (1926).

692 Rostovtzeff, Social aNd Economic History of the Hellenistic World 788 (1941).

701 id. at 397 ; GLotz, op. cit. supra note 68 , at 368-69.

715 Frank, An Economic Survey of ANCIENT Rome 249-50 (1938).

72 See $3 i d$. at 303.

735 id. at 270; CAsson, op. cit. supra note 67, at 179-80.

744 Frank, An Economic SuRVey of ANCIENT RoNe 408-09 (1938).

75 Ibid.

765 id. at 220. 
work. Where there was no other group available, the sailor was called on to perform it. However, in these instances it was treated as extra work and compensated for as such.

\section{The Effect of the Extension of the Seaworthiness DOCTRINE}

\section{A. The Individual Longshoreman}

Few compensation acts provide greater benefits for the disabled worker than does the Longshoremen's and Harbor Workers' Compensation Act. ${ }^{77}$ Present maximum benefits under that act are $\$ 70$ per week, free of all taxes. ${ }^{78}$ Provision is also made for all medical, hospital, and nursing services. ${ }^{79}$ And yet, Sieracki gives the worker the alternative of suing a non-negligent shipowner with the guarantee that his recovery will be at least what he is entitled to under compensation. ${ }^{80}$ Although the Supreme Court's motivations in Sieracki were humanitarian, an examination of the available evidence raises doubt that, in practice, the doctrine has been the humanitarian instrument the court intended.

In Holley $v$. The Manfred Stansfield, ${ }^{81}$ a longshoreman's widow was the plaintiff. At the time the award was made, her attorney obtained $50 \%$ of the total award as his fee. ${ }^{82}$ Counsel involved in the case reports that the net cash recovery to the widow was $\$ 1,597.45$, out of a gross cost to the employer of $\$ 24,293.71$. It is estimated that the recovery under compensation would have been $\$ 23,790.65$ - to which the widow would have been entitled without litigation. Of course, she still got that amount, for the Compensation Act provides that if the net recovery against the third party is less than it would have been under compensation, compensation makes up the difference. ${ }^{83}$ Thus, a case which should have required the expenditure of $\$ 23,790.65$ was increased to $\$ 46,486.91$ with no increase in the net benefit to the widow.

In another case in which a longshoreman had been killed, the total settlement was $\$ 215,000$. Of that sum, there remained for distribution to the widow and five dependent children $\$ 141,017.51$ after deductions for "fees, costs and a claim in subrogation." 84

7744 Stat. 1424 (1927), 33 U.S.C. \$901 (1958).

7875 Stat. 203 (1961), 33 U.S.C.A. \$ 906 (Supp. 1962).

7944 Stat. 1427 (1927), as amended, 33 U.S.C. $\$ 907$ (1958).

8073 Stat. 391 (1959), 33 U.S.C. § 933(f) (Supp. II, 1961).

81186 F. Supp. 212 (E.D. Va. 1960).

82 Holley v. The Manfred Stansfield, 186 F. Supp. 805, 809 (E.D. Va. 1960). The court declared that "fair and reasonable compensation" for the plaintiff's attorney "is fixed at one-half of the recovery."

8373 Stat. 391 (1959), 33 U.S.C. \$ 933(f) (Supp. II, 1961).

81 Olson Estate, $25 \mathrm{~Pa}$. D. \& C.2d 622, 625 (Orphans' Ct. 1961). 
Many people believe that compensation is a mere pittance, but that belief hardly accords with the facts. A widow recently instituted suit rather than accept compensation for the death of her husband. ${ }^{85}$ The settlement called for an award of $\$ 80,000$. An attorney's fee of $\$ 26,174.92$, plus other expenses incurred by the attorney of $\$ 1,474.25$ left the widow and children $\$ 52,349.83$. No one really questioned whether the attorney had rendered the family a service since the widow now had more than $\$ 50,000$ in cash, yet the benefits payable over a period of years would have amounted, under compensation, to $\$ 94,110.84 .^{86}$

There is also a real question whether longshoremen or their dependents, unaccustomed by training or experience to manage an investment program, are better protected by regular weekly payments or lump-sum awards. One successful longshoreman-plaintiff ${ }^{87}$ drove his 33-foot cabin cruiser aground. ${ }^{88}$ A rough rule of thumb is that cabin cruisers cost about $\$ 1,000$ per foot. On any such basis, the cruiser must have represented a very substantial percentage of his net recovery. That a cabin cruiser served the longshoreman's best interest from a humanitarian viewpoint may be open to question.

\section{B. The Maritime Industry}

In the sixteen year period since Sieracki was decided, approximately forty-four American steamship companies have ceased to operate, or are presently in the process of withdrawal and liquidation. ${ }^{89}$ This is confined to companies directly involved with the stevedoring problem and excludes harbor craft, tankers, and specialized vessels

85 Caulfield v. Calmar S.S. Corp., Civil No. 25890, E.D. Pa., May 18, 1962.

86 In this case, the decedent's wages were $\$ 5500$ per year; widow's age was 43 ; her life expectancy was 36.7. OfFice of VITal Statistics, U.S. Dep'T of Heazth, Education \& Welfare, LIfe Tables. At the time of death, the children were 8 years, 7 years, 5 years, and 4 years respectively. The computation is as follows:

$\$ 70.00$ per week $\times 52$ weeks $\times 11$ years ( $35 \%$ of wages to widow;

$15 \%$ for each child; maximum $\$ 70.00$ weekly) ........... $\$ 40,040.00$

12th and 13th years (second child then 18) $\ldots \ldots \ldots \ldots \ldots \ldots \ldots ., 7,098.00$

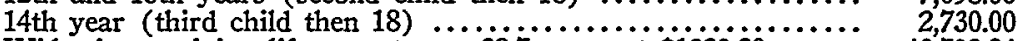

Widow's remaining life expectancy, 22.7 years at $\$ 1929.20 \ldots \ldots .443,792.84$

Total recovery . ................................... $\overline{94,110.84}$

Social Security benefits would accrue in addition. Of course, to achieve a meaningful comparison, the $\$ 94,110.84$ must be reduced to present worth.

87 Brabazon v. Belships Co., 103 F. Supp. 592 (E.D. Pa. 1952), aff'd, 202 F.2d 904 (3d Cir. 1953).

88 Phila. Evening Bulletin, Oct. 26, 1959, p. 5, col. 1.

89 Included in this list are some companies which have ceased operation and surrendered their franchises, and whose ships are now for sale. 
which do not need large numbers of longshoremen working on and about the ship. ${ }^{80}$

There are, of course, other factors which led to the demise of American shipping. Its problems have been many. That the added costs of longshoremen's injury claims is, however, a factor-and probably a substantial one-is demonstrated by the fact that the attrition rate has been the greatest in coastwise and inter-coastal shipping which is constantly exposed to the effects of the doctrine by repeated and frequent calls at American ports. To the best of our knowledge there are no steamship companies still engaged in coastwise carriage of general cargo on the Atlantic, the Gulf, or the Pacific coasts. ${ }^{91}$ The intercoastal fleet has been reduced from 123 to twelve ships, operated by only two companies, Calmar Steamship Corporation and Weyerhaeuser Steamship Company. Neither is a common carrier in the true sense of the term, for each confines itself principally to carrying pulp and lumber eastbound and steel westbound. It is possible, but doubtful, that the Supreme Court in Sieracki foresaw this revolution in ocean transportation.

Congress, through the Maritime Administration, has sought to build up the American fleet and the American merchant marine. The Defense Department has encouraged this function in order to cope with its logistics problems. However, an effect of the application of the unseaworthiness doctrine to longshoremen has been to help to destroy faster than the Federal Maritime Board can build. ${ }^{92}$

Precise figures on the total cost to the industry are not available. There is information from a variety of sources which makes it possible to formulate certain conclusions. Between 1945-the last pre-Sieracki year-and 1954, insurance rates rose $600 \%$ and seven companies had withdrawn from writing the insurance which covers such liability. ${ }^{93}$ Largely as the result of indemnity in favor of the shipowner against the stevedore, ${ }^{94}$ insurance rates for the latter have increased from

90 E.g., Seatrain Lines and Sea-Land Service which carry rail cars and trailer bodies in coastal commerce.

91 Excepting Seatrain Lines and Sea-Iand Service, both specialized carriers.

02 Merchant Marine Act, 49 Stat. 1985 (1936), as amended, 46 U.S.C. \$1101 (1958). Its purposes are to foster development and maintenance of a merchant marine of well-equipped and suitable vessels, not only for commerce but as auxiliaries in time of war or national emergency. Actually subsidies were narrowly confined to eleven companies-the "Twelve Apostles" having been reduced to that number by the demise of Seas Shipping Co. Time, Feb. 22, 1963, p. 82, recently noted that while "more than half the U.S. ships in overseas trade are already on subsidy to the tune of $\$ 300$ million" annually, this has not been enough to prevent a $41.9 \%$ reduction in the fleet in the last ten years, from 933 to 542 .

93 Tetreault, Seamen, Seaworthiness, and the Rights of Harbor Workers, 39 CoRNELI L.Q. 381, 417 n.163 (1954).

94 Waterman S.S. Corp. v. Dugan \& McNamara, Inc., 364 U.S. 421 (1960); Crumady v. The Joachim Hendrik Fisser, 358 U.S. 423 (1959); Ryan Stevedoring Co. v. Pan-Atlantic S.S. Corp., 350 U.S. 124 (1956). 
"approximately $\$ 7.00$ per $\$ 100.00$ of payroll" in 1954,95 to $\$ 18.60$ in November of 1962.96 That does not take into account the losses of the steamship companies for which indemnity is not obtained.

Estimates of the total "bill" range from ten to eighteen million dollars per year, ${ }^{97}$ using calculations based upon the total payroll for the stevedoring industry. If the estimates can serve as a basis for calculation, the amounts involved in a span of years are staggering. The attrition which these costs produce in the industry creates unemployment for sailors and longshoremen. ${ }^{98}$ There is more than a single facet to "humanitarianism."

The first eight monthly advance sheets of American Maritime Cases for 1962 reveal seventy reported decisions involving claims by longshoremen based upon "unseaworthiness." This includes all courts throughout the country. Four law firms represented thirty-four of the plaintiffs, indicating a considerable degree of concentration. Of course, no more than three or four percent of all suits filed go to trial. An even smaller percentage result in a published opinion. In many cases there are either no post-trial motions by the defendant, or the motions are denied without opinion. Only an infinitesimal percentage of the total ever reaches an appellate court.

Can any conclusion be drawn from all this? It seems arguable that approximately $40 \%$ of the total estimated cost to the industry of the extension of the unseaworthiness doctrine is for lawyers' fees, ${ }^{99}$ and half of that would appear to be divided among a very few law firms. To suppose that insurance companies bear the loss is another flight of fancy. Some steamship companies carry no insurance to cover risks such as this. High cost and the belief that an efficient companywhere efficiency can reduce losses-must contribute to the losses of the inefficient, ${ }^{100}$ plays a part in this decision. More important, however, is the fact that insurance companies do not bear the loss in any true sense. The rates charged are based upon loss experience, and in the great majority of instances they are retrospective or are carried in mutuals whose participants are subject to "calls" as losses must be paid.

95 Tetreault, supra note 93 , at 417. 1962.

96 Letter From Counsel for New York Shipping Ass'n to the authors, Nov. 28,

97 Hearings on Warranty of Seazuorthiness: Third Party Liability, Before the Subcommittee on Merchant Marine of the House Conmittee on Merchant Marine and Fisheries, 87th Cong., 1st Sess. 16 (1961).

98 Between 1956 and 1960 there was a decrease of $19.26 \%$ in the total man-hours worked by all longshore labor in the Port of Philadelphia. Philadelphia Marine Trade Ass'n-International Longshoremen's Ass'n Central Records Bureau. Between 1951 and 1961 the drop was $28.5 \%$ or 912 jobs averaging 1500 work hours per year.

99 That does not include the fees and expense of defending the actions.

100 The cost of negligently inflicted injury has been cast out of the calculations used herein. However, one insurance covers both. 
Under such systems, the losses are simply totalled. To that total is added the cost of what insurance companies call "production" [the sales commission] and the pro rata share of the insurance companies' other costs, overhead, and profit. Some convenient divisor-usually tonnage of the ships covered-is divided into that total and that becomes the rate the shipping company pays for its insurance. The only time an insurer cannot reimburse itself is when, after a catastrophic loss, ${ }^{101}$ the insured is able to shift to another underwriter who is willing to ignore part of the loss in order to get the business. This is sometimes done in the belief that history of that sort will not repeat itself. ${ }^{102}$

An underwriter who operated differently would not long be competitive. If it paid part of the shipping company's losses with profits from another line of business, it would soon lose it competitive position since neither its marine risks nor its other risks would show sufficient profit to justify continuance without a rate increase. It is for these reasons that insurers operate as they do, and for these same reasons they will simply stop writing a line of insurance which does not show a profit over the long haul.

That premiums are high may not, in fact, be undesirable from the standpoint of the underwriter. The higher premium gives it an opportunity to make a greater investment income during the period between the time the premium is collected and the time that same money must be paid out to satisfy an adverse judgment. There is another advantage. Insurers value their relations with large brokers who, in the course of years, have much business of all kinds to place. The brokers' income is usually a percentage of the premium. There is, therefore, little incentive on the part of the insurance industry for lower premiums.

\section{CoNCLUSION}

Imposition of absolute liability based upon a judicial determination that stevedoring is "hazardous" will not withstand analysis. Loading and unloading ships is not as hazardous as many other occupations. Steel erection, mining, and logging are examples which come readily to mind. The federal judiciary, we suggest, has simply been more aware of the hazards of stevedoring due to its prolonged exposure to a greater number of personal injury suits by longshoremen than by any other class except possibly railroad workers. This is probably attributable to the higher awards given by federal juries and the fact that longshoremen can get into federal court under admiralty as well as

101 Such as the loss of a vessel and crew. See The Mormackite, 184 F. Supp. 585 (S.D.N.Y. 1960).

102 Such was the actual fact after the loss of the Mormackite and the heavy losses there involved. 
diversity jurisdiction. The concept of stevedoring as a hazardous or ultra-hazardous occupation prompted federal judges to search for-and find-new grounds upon which to justify damage awards. The judges were probably further motivated by the fact that a lump-sum award always seems larger than a compensation award paid over. a period of time.

The recent trend toward indemnity awards to the shipowner from the stevedore ${ }^{103}$ may be the result of judicial recognition of the damage done to the shipping industry from this application of the "warranty of seaworthiness." At best, this is a stopgap measure since it makes little difference whether shipping companies cannot compete because of large damage awards against them or because of high stevedoring charges. The dollar the stevedore pays the ocean carrier today by way of indemnity will be added to the stevedoring rate tomorrow. That rate in turn increases the cost of transportation, thus extending the effect beyond the shipping industry. A difference of only two or three cents in freight rates frequently determines whether a foreign buyer purchases products of American or European manufacture. ${ }^{104}$ The European Common Market will have a serious enough effect upon our export market without the additional factor of increased transportation costs. Moreover, this policy of indemnification seems to clash with congressional intent. The obligation to pay benefits regardless of fault was made "exclusive and in place of all other liability of such employer . . . to the employee . . . ." 105

It is doubtful that anyone benefits when one jury verdict can wipe out the earnings of a ship for an entire year. That recoveries for unseaworthiness are in the humanitarian interests of the class for whose benefit the doctrine was designed, is far from clear. We submit, however, that one fact is abundantly certain. The courts have either misread, or have not read, the facts of history. The results have been farreaching and the end is by no means in sight.

103 See cases cited note 94 sipra.

104 See Tetreault, supra note 93, at $417 \mathrm{n} .164$ and text accompanying note 93 supra. 10544 Stat. 1426 (1927), 33 U.S.C. §905 (1958).

[As this Article was going to press, the United States Supreme Court announced its decision in Reed v. Steamship Yaka, 31 U.S.L. WEEK 4528 (U.S. May 27, 1963). The Court held that compensation was not necessarily the exclusive remedy of the longshoreman against his employer. Therefore, notes $12 \& 105$ and accompanying text are no longer accurate.] 